\title{
Manifestation And Endoparacitic Intensity On Gonggong Conch (Laevistrombus turturella)
}

\author{
Muzahar Muzahar*, Aminatul Zahra , Rika Wulandari \\ Aquaculture Department, Faculty of Marine Sciences and Fisheries, Raja Ali Haji Maritime University, Indonesia
}

\begin{abstract}
Habitat the gonggong conch (Laevistrombus turturella) also known as Dog conch is a species from the Gastropod class that can be found in shallow waters with muddy sand substrate. In Kepulauan Riau Province, these animals are hunted by fishermen to sell to consumers since gonggong conch is a favourite culinary in this province. The availability of conch in the market has only relied on natural catches. The high consumption and natural fluctuations have decreased the conch population. To maintain the sustainability of the dog conch, it is necessary to carry out the cultivation activities. The cultivation begins with the selection of quality broodstock. The gonggong conch of natural origin needs to be determined before cultivation, in order to prevent the entry of disease in the cultivation system i.e. parasites. This study includes the determination, prevalence and infection intensity of endoparasites in conch from Madong Bay, Tanjungpinang. The results showed that the total length of the conch shells ranged from 55.5 to $79.5 \mathrm{~mm}$ with an average length of $67.72 \mathrm{~mm}$ and a frequency mode of $64.6 \mathrm{~mm}$. The sex ratio between male and female conch is 1:1.1 (not ideal) $n=30$. Two kinds of parasites were found in the digestive tract of gonggong conchs are conoidacid oocysts and trematode sporocysts. The number of endoparasites, prevalence and intensity in wild caught has high numbers involving conoidacid oocysts (prev=100\%; $\mathrm{I}=48.23 \mathrm{ind} / \mathrm{conch}$ ) and trematode sporocysts (prev $=100 \%$; I= 135.33 ind/conch). It was concluded that the level of endoparasites infection in the dog conch from the Madong Bay was categorized as moderate-to-severe.
\end{abstract}

\section{Introduction}

The gonggong conch (Laevistrombus turturella) is a type of sea conch which is a soft-bodied animal from the gastropod class that mostly lives on the coast of Bintan Island, Kepulauan Riau Province. In this area, gonggong conch is a leading fishery commodity with a high level of consumption in addition to fish and crabs. Because of its popularity, this animal is crowned as an icon of the Tanjungpinang City. The gonggong conch population in the waters of Bintan Island and its surroundings has experienced "growth overfishing", where the population of this animal is unable to face the pressure of collection by the population, because its growth is relatively slow while the availability of stocks only relies on natural catches. To maintain the sustainability of the gonggong resource, it is necessary to start a cultivation activity. Gonggong conch cultivation activities begin with the selection of broodstocks from nature. Determination of the broodstocks from nature is intended to prevent pathogens from entering the cultivation system e.g. parasites.

Parasite is an organism whose life depends on another organism called a host and absorbs nutrients from that place of life. Parasites have an impact on reducing body weight of biota, body resistance and quality. Thus, these conditions trigger secondary infection by other pathogens and even lead to death.
There are no available reports regarding the type and distribution of parasites in gonggong conch and addressing the dangers that arise from parasitic attacks. To fill this gap, it is important to do this research. This study aims to determine the prevalence and degree of parasitic infection of the endoparasite group in gonggong conch from the waters of Madong Bay, Tanjungpinang.

\section{Methods}

This research was conducted from August to September 2021 at the Marine Biology Laboratory, Faculty of Marine Sciences and Fisheries, Raja Ali Haji Maritime University. The stages of the research were carried out natively. A total of 30 gonggong conchs were taken in the waters of Madong Bay, Tanjungpinang City. The samples are then taken to the laboratory to measure their total length $(\mathrm{mm})$ using a caliper. The gonggong shell was then opened and the lesions on the body surface were examined using a Lup glass and gender identification. The research was continued with endoparasite examination anchored [1]. The digestive organs were dissected (abdominal) and the contents of the stomach (gastrointestinal) were removed and then placed in a petri dish containing a physiological solution. Observations of endoparasites were conducted with a digital microscope with a magnification of $300 x$.

\footnotetext{
* Corresponding author: muzahar@umrah.ac.id
} 
Prevalence and intensity were calculated using the following [2] formula:

Prevalence $(\%)=($ number of fish infected with parasites) / (fish examined) x 100

Intensity $=($ number of parasites found $) /$ (number of infected fish) $\times 100 \%$

Data on the total length of gonggong, sex, number and types of parasites obtained are presented in tables and figures. The results of data analysis are discussed descriptively by comparing the results of other related studies.

\section{Result and Discussion 3.1 Morphometrics and Sex Ratio of Gonggong conchs (L. turturella)}

The morphometric characteristics of gonggong conch that were measured in this study amounted to six parameters including the sex ratio. The morphometric values are presented in Table 1.

Table 1. Morphometric of Gonggong conchs (L. turturella)

\begin{tabular}{cc}
\hline Parameters & Values (mm) \\
\hline $\mathrm{P}_{M}$ & $59.80-76.90$ \\
$\mathrm{P}_{F}$ & $55.50-79.50$ \\
\hline$\overline{\boldsymbol{X}} \boldsymbol{p} \boldsymbol{M}$ & $67.51 \pm 0.52$ \\
$\overline{\boldsymbol{X}} \boldsymbol{p} \boldsymbol{F}$ & $67.96 \pm 0.59$ \\
\hline$\overline{\boldsymbol{X}} \boldsymbol{p} T$ & $67.72 \pm 0.55$ \\
\hline M $o$ & $64.60 \pm 0.55$ \\
\hline Sex ratio & $1: 1.1$
\end{tabular}

Note: PM / F = Length of male / female; X p M/F = Average length of male/female; $\mathrm{X} \mathrm{p} \mathrm{T} \mathrm{=} \mathrm{Average} \mathrm{total}$ length; Mo $=$ Frequency mode

Table 1 shows that the size of the female gonggong conch tends to be longer than the male gonggong conch. The value of the morphometric mode proportion of the gonggong conch's length is $64.60 \mathrm{~mm}$ with a sex ratio of $1: 1.1$ (not ideal) [3] reported that the sex ratio of male and female gonggong conchs in the waters of Madong bay was not balanced since the number of male gonggong conchs tended to be not the same as the number of females gonggong conchs. The unbalanced sex ratio of gonggong conchs is strongly assumed by excessive exploitation pressure [4].

\subsection{Types of Endoparasites in the Gonggong Conch Digestive Tract}

The examination of the contents of gonggong conch digestive tract figured out two types of endoparasites, there are from the class of Conoidacid and Trematode in the form of oocysts and sporocysts (Figure 1). Conoidacid is a type of sporon-forming protozoa that utilizes host species of mammals, birds and fish. The identification of Conoidacid oocyst was based on the morphology of the parasite and the visible nucleus. Conoidacids in the gonggong conch gastrointestinal tract were found in the form of non-sporulating oval oocysts containing one nucleus and were non-infective. No sporoblasts containing sporozoites were also identified, whereas mature oocysts will contain four or more sporocysts with two sporozoites each, depending on the genus. Oocysts enter the gonggong conch body through their diet which tends to erode detritus on the substrate. This thick-walled oocyst makes it resistant to the acidic conditions of the gastrointestinal tract.

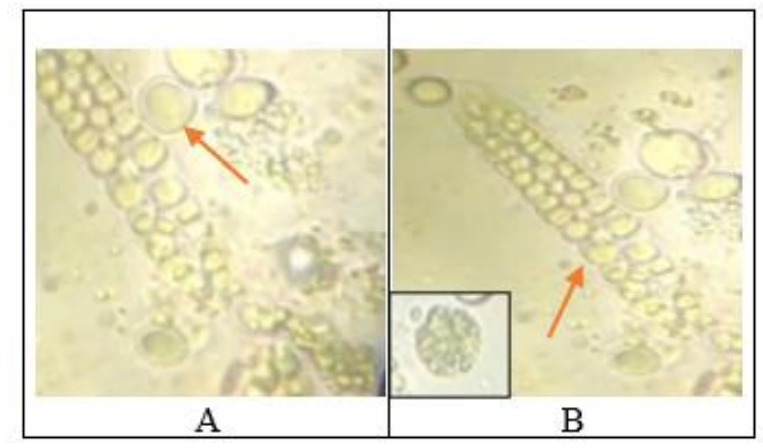

Figure 1. Conoidacid oocysts (A); Trematode Sporocyst (B)

Trematodes are a class of parasites belonging to the phylum Platyhelminthes. In their life cycle, there are various stages of Trematodes i.e. miracidia, sporocysts, redia, cercariae, and metacercariae. Trematodes in the study were found at the sporocyst stage in two forms, namely young and adult sporocysts. The identified young sporocysts have a round body shape, short with notched edges, while the adult sporocysts are elongated like a pouch and cylindrical and the body is smooth with grooved edges and with blunt anterior and posterior ends. On the inside of the sporocyst, there are granules which are germ cells. Germ cells will multiply and form a new germ mass. These germ cells will develop into redia. One sporocyst or redia can produce more than ten cercariae. This reproductive ability is quite high, because only one egg can produce sporocysts or redia and be capable of giving birth to millions of cercariae in the body of an intermediate host. This pattern of reproduction is called asexual polyembryony. These trematodes are invasive, where only one genus of the strongest trematodes can inhabit the host

\subsection{Endoparasites Prevalence and Intensity in Gonggong Conchs}

Based on the calculation of the prevalence of endoparasites, it reveals that Conoidacid oocysts and Trematode sporocysts infect all gonggong conchs samples with a percentage of $100 \%$, the category of infection is always or very severe infection. Endoparasite prevalence values are presented in Table 2.

Table 2. Prevalence of L. turturella endoparasites

\begin{tabular}{lcccc}
\hline $\begin{array}{c}\text { Endoparasit } \\
\text { es }\end{array}$ & $\mathbf{n}$ & $\begin{array}{c}\mathbf{n} \\
\text { infection }\end{array}$ & $\begin{array}{c}\text { n non- } \\
\text { infecti } \\
\text { on }\end{array}$ & $\begin{array}{c}\text { Prev } \\
(\%)\end{array}$ \\
\hline $\begin{array}{l}\text { Oocysts } \\
\text { Conoidacid }\end{array}$ & 30 & 30 & 0 & 100 \\
\hline Sporocysts & 30 & 30 & 0 & 100
\end{tabular}

Trematode

Note: Prev $=$ Prevalence; $\mathrm{n}=$ number of samples 
The high prevalence of endoparasites in the gastrointestinal tract is in line with the high prevalence of parasites in nature $[5,6]$. This is triggered by various factors, such as pollution, imbalance between host and pathogen, and survival of parasitic eggs [7]. Parasite prevalence and intensity categories [3] as in Table 3 and 5.

Table 3. Parasite prevalence categories

\begin{tabular}{lll}
\hline Prevalence & Category & Description \\
\hline$<0,01$ & $\begin{array}{l}\text { Almost } \\
\text { never }\end{array}$ & Infection never \\
\hline $0,01-0,1 \%$ & Very rare & Very rare infection \\
\hline $0,1-1 \%$ & Rarely & Rare infection \\
\hline $1-9 \%$ & Sometimes & Infection sometimes \\
\hline $10-29 \%$ & Frequent & Frequent infections \\
\hline $30-49 \%$ & Commonly & common infections \\
\hline $50-69 \%$ & Very often & $\begin{array}{l}\text { Very frequent } \\
\text { infection }\end{array}$ \\
\hline $70-89 \%$ & Usually & moderate infection \\
\hline $90-98 \%$ & $\begin{array}{l}\text { Almost } \\
\text { always }\end{array}$ & Severe infection \\
\hline $99-100 \%$ & Always & very severe infection \\
\hline
\end{tabular}

Intensity is the average number of parasites per infected fish sample. The results of the calculation of endoparasite intensity are presented in Table 4.

Table 4. Intensity of L.turturella endoparasites

\begin{tabular}{lcccc}
\hline $\begin{array}{l}\text { Endoparas } \\
\text { ites }\end{array}$ & n & $\begin{array}{c}\text { n } \\
\text { infectious }\end{array}$ & $\begin{array}{c}\text { n non- } \\
\text { infecti } \\
\text { ous }\end{array}$ & $\begin{array}{c}\text { I } \\
\text { (ind/tail } \\
\text { s) }\end{array}$ \\
\hline $\begin{array}{l}\text { Oocysts } \\
\text { Conoidacid }\end{array}$ & 30 & 30 & 0 & 48.23 \\
\hline $\begin{array}{l}\text { Sporocysts } \\
\text { Trematode }\end{array}$ & 30 & 30 & 0 & 135.33 \\
\hline
\end{tabular}

Note: $\mathrm{I}=$ Intensity; $\mathrm{n}=$ number of samples

Based on the results presented in Table 5, endoparasites of the conoidacid oocyst type infect all gonggong conchs with an intensity of 48.23 ind/bird, and the intensity of endoparasites with trematode sporocysts is higher at $135.33 \mathrm{ind} / \mathrm{bird}$.

Table 5. Parasite intensity categories

\begin{tabular}{ll}
\hline Intensity & Category \\
\hline$<1$ & Very low \\
\hline $1-5$ & Low \\
\hline $6-55$ & Medium \\
\hline $51-100$ & Severe \\
\hline$>100$ & Very severe \\
\hline$>1000$ & Super infectiobs \\
\hline
\end{tabular}

The category of conoidacid oocyst infection was in the moderate category, while the trematode sporocyst infection was in the very severe category. The high intensity value is also influenced by the survival factor of endoparasite eggs and pollution and poor environmental quality.

\section{Conclusion}

Based on the morphometric characteristics, data obtained indicate that the size range of female gonggong conchs are longer than that of male gonggong conchs with an unbalanced sex ratio between males and females. This condition may be triggered by exploitation pressure. Two types of endoparasites were found, namely conoidasida oocysts and trematode sporocysts with a prevalence of $100 \%$ infection. Further, the degree of infection was in the moderate and very severe categories.

\section{Acknowledgement}

The authors would like to thank all members of the research team for their cooperation so that this research can be completed on time. The authors also thank the Raja Ali Haji Maritime University through the funding of UMRAH Internal research.

\section{References}

1. C. M. Adema and E. S. Loker, Developmental \& Comparative Immunology 48, 275 (2015).

2. Z. Kabata, Parasites and Diseases of Fish Cultured in the Tropics (Taylor \& Francis Ltd, 1985).

3. L. N. Hakim, H. Irawan, and R. Wulandari, Intek Akuakultur 3, 45 (2019).

4. R. W. N. Waris, L. W. Zen, and A. Zulfikar, Jurnal Umrah 1 (2015).

5. M. Beveridge, Cage Aquaculture Third Edition (Blackwell Publishing Ltd, n.d.).

6. A. W. Sarono and E. S. Haryani, Deskripsi Hama Dan Penyakit Ikan Karantina Golongan (1993).

7. M. Woolmark and L. Pritchett, Solutions When the Solution Is the Problem: Arraying the Disarray in Development, Center for Global Development (Washington, DC, 2002). 